\title{
The effects of intake of lucerne (Medicago sativa L.) and orchard grass (Dactylis glomerata L.) hay on the motility of the forestomach and digesta flow at the abomaso-duodenal junction of the sheep
}

\author{
BY C. H. MALBERT AND R. BAUMONT \\ Laboratoire associé INRA de Physiologie, Ecole Nationale Vétérinaire, 31076 \\ Toulouse Cédex, France
}

(Received 17 February 1988 - Accepted 28 October 1988)

\begin{abstract}
1. The relations between food intake, reticulo-ruminal motility and abomasal digesta outflow were investigated in ewes receiving lucerne (Medicago sativa) v. orchard grass (Dactylis glomerata) hay. Abomasal digesta outflow was recorded continuously by means of an electromagnetic flowmeter probe inserted into a duodenal T-shape cannula and the motility using strain-gauge force transducers. Volumes and turnover rates of both rumen and abomasal liquid phases were measured by CrEDTA dilution.

2. The voluntary intake of lucerne was higher $(60 \%)$ than that of orchard grass hay, and paralleled by an increased abomasal outflow $(65 \%)$ corresponding to an increased number of gushes of digesta through the flowmeter probe: $129 / \mathrm{h}$ instead of $78 / \mathrm{h}$ on orchard grass hay. Abomasal motor activity was enhanced $(35 \%)$, and periods of regular spiking activity were seen passing along the duodenum at a higher velocity for the lucerne diet than for the orchard grass diet. The increased abomasal outflow with lucerne hay was associated with a higher reticulo-ruminal turnover rate, but not abomasal turnover rate. Abomasal, but not reticulo-ruminal volume, was increased $(30 \%)$ when lucerne hay was fed ad lib.

3. The total number of reticulo-ruminal contractions was increased by $6.6 \%$ when the dry matter entering the duodenum was increased by $70.6 \%$, suggesting the level of voluntary intake, rather than reticulo-ruminal motility, as a major factor governing abomasal outflow in sheep.

4. More frequent passages of digesta, unrelated to duodenal contractions, were recorded in ewes receiving lucerne compared with orchard grass. Both a higher viscosity of the contents due to the addition of guar gum and the impairment of antroduodenal motility by 5-hydroxytryptophan were able to reduce the fiow rate of orchard grass digesta, but did not affect the higher flow rate of lucerne digesta. The findings suggest that the high abomasal outflow in sheep fed on lucerne ad lib. is related to a low viscosity of the contents that are propelled, even in the case of antral contractions of low magnitude.
\end{abstract}

Legumes are eaten by ruminants in greater amounts than grasses at the same level of maturity (Jarrige, 1978). The lower cell wall content and the higher content of soluble constituents of legumes allow higher rates of digestion (Demarquilly \& Chenost, 1969; Noceck \& Grant, 1987) and shorter retention times in the reticulo-rumen (Minson, 1966). The subsequent lower degree of distension and fill of the reticulo-rumen can be a causative factor of a higher voluntary intake. Moreover, the relation between the level of food intake and the volume of gastric outflow has been emphasized in both the preruminant calf (Sissons, 1983) and the adult sheep (Gregory et al. 1985).

Nevertheless, the increased digesta flow did not seem to be accompanied by major changes in the gastroduodenal motor activity. In the non-ruminant species, the motility of the proximal stomach, i.e. the fundus, has been regarded as the main regulating factor of the emptying rate of liquid (Hunt \& Stubbs, 1975). A role in the gastric emptying rate could also be attributed to the distal stomach, i.e. the antrum (Hinder \& San-Garde, 1983). In the milk-fed calf, the origin of changes could rely on duodenal influences (Bell \& Watson, 1976), since the first part of the duodenum has been identified as a very sensitive receptor area, able to reduce the motor activity of the abomasum and thus its emptying rate (Bell \& Grivel, 1975). A duodenal origin in sheep of the periodic inhibition of antral motility has also been suggested (Ruckebusch, 1975). Abomasal contractions periodically ceased at the onset on the duodenum of the phase of regular spiking activity (RSA) and during the 
subsequent phase of quiescence or no spiking activity (NSA) of the myoelectric migrating complex (MMC); the higher the flow rate, the shorter the duration of the phase of quiescence.

The amount of digesta entering the duodenum, measured with good accuracy using marker techniques (MacRae, 1974; Faichney, 1975), provides only mean daily values under steady state conditions. On the other hand, direct measurements of duodenal flow by total collection (Oldham \& Ling, 1977; Wanderley et al. 1985) or by means of an electromagnetic flowmeter (Singleton, 1961; Poncet et al. 1977) required a re-entrant cannula, which is known to alter duodenal motility (Wenham \& Wyburn, 1980). Among the approaches used to record chronically the abomasal outflow (Sissons \& Smith, 1978), a ring-like electromagnetic probe inserted into a T-shape cannula, with processing of the signal of the flowmeter via a computer program, was recently validated. The minute-tominute flow rate of chyme depended on the strength of antral contractions and also the viscosity of the contents (Malbert \& Ruckebusch, 1988).

The present experiment was designed to study the variations of abomasal outflow related to the nature of the diet and levels of voluntary intake, i.e. low intake of orchard grass (Dactylis glomerata L.) hay compared with the higher intake of lucerne (Medicago sativa L.) hay, and to the intake of lucerne hay limited at the level of orchard grass. More precisely, the attempt was to define the role of the level of voluntary intake, reticulo-ruminal motility, and motor patterns at the abomaso-duodenal junction involved in the high minute-to-minute flow rate of lucerne digesta.

\section{MATERIALS AND METHODS}

\section{Animals}

Seven adult Lacaune ewes $(54.5$ (SE 1.7$) \mathrm{kg}$ ), housed in metabolism crates under a $12 \mathrm{~h}$ light-dark schedule, were used. Four animals were fitted, using aseptic conditions under penthiobarbital sodium (Nesdonal: $20 \mathrm{mg} / \mathrm{kg}$ ) anaesthesia, with a silastic rumen cannula (internal diameter $30 \mathrm{~mm}$ ), an antral silastic tube (diameter $10 \mathrm{~mm}$ ); two strain-gauge $(15 \times 10 \mathrm{~mm})$ transducers were sewn onto the serosal side of the reticulum and the dorsal sac of the rumen, and a silastic $T$-shape cannula (internal diameter $25 \mathrm{~mm}$ ) inserted along the antimesenteric border of the duodenum $40-50 \mathrm{~mm}$ from the pylorus beyond the duodenal bulb. One set of nickel-chromium wire (120 $\mu \mathrm{m}$ in diameter) electrodes was fixed on the duodenal bulb in order to assess the periods of no spiking activity.

The remaining three ewes received four sets of $\mathrm{Ni}-\mathrm{Cr}$ wire electrodes to record the electrical activity of the gastroduodenal area. The electrodes were implanted as previously described (Ruckebusch, 1970) on the antrum approximately $50 \mathrm{~mm}$ from the pylorus, and the duodenum approximately 20 and $100 \mathrm{~mm}$ from the pylorus. The electrical activity of the transverse duodenum at about $500 \mathrm{~mm}$ from the pylorus was considered as representative of the cyclical activity of the small intestine with the sequence of irregular spiking activity (ISA, $90 \mathrm{~min})$, RSA (2-3 min) and NSA (8-13 $\mathrm{min})$ phases for the MMC (Ruckebusch \& Buéno, 1977). Two strain-gauge transducers were sewn perpendicular to the longitudinal axis of the antrum at about $50 \mathrm{~mm}$ before the pylorus and the duodenal bulb, $20 \mathrm{~mm}$ beyond the pylorus. A silicone tube (internal diameter $10 \mathrm{~mm}$ ) was inserted inside the lumen of the abomasum. A T-shape duodenal cannula (internal diameter $25 \mathrm{~mm}$ ) was fixed on the antimesenteric border of the duodenum at $40-50 \mathrm{~mm}$ from the pylorus in order to insert, 2 weeks after the surgery, the ring-like probe of an electromagnetic flowmeter inside the duodenal lumen (Malbert \& Ruckebusch, 1988). 


\section{Experimental design}

A late cut orchard grass hay and a second cycle lucerne hay were used. The animals were fed twice daily (at 09.00 and 17.00 hours) ad lib., except when lucerne hay was given at the dry matter intake of orchard grass, and had free access to water and salt block. The refusals were weighed before morning and afternoon distribution. Sampling of duodenal contents was performed at $3 \mathrm{~h}$ intervals over $24 \mathrm{~h}$ during orchard grass- and lucerne hay-fed periods, in order to determine density and also dry matter (DM), organic matter, nitrogen and cell wall contents. Abomasal contents were also sampled on ewes fed for at least $3 \mathrm{~d}$ with orchard grass or lucerne hay in order to test the viscosity at $38^{\circ}$ with a rotating viscosimeter at a shear rate of 14/s (Rotoviscometer, model RV3; Haake).

The viscosity of abomasal contents was increased in the three ewes fitted with four sets of electrodes on the gastroduodenal area through a bolus administration of guar gum $(50 \mathrm{~g} / 1,100-150 \mathrm{ml}$, depending on the volume of abomasal contents) by the abomasal tube. This amount of guar gum was able to decrease by $30-50 \%$ the gastric emptying rate without affecting the motility patterns in dogs (Russell \& Bass, 1985).

On the same ewes, the serotonin precursor (5-hydroxytryptophan; 5-HTP) was administered intravenously at a dose $(0.3 \mathrm{mg} / \mathrm{kg})$ able to enhance the antroduodenal motility (Ruckebusch \& Malbert, 1986).

In two ewes fitted with gastroduodenal electrodes and strain gauges which continued to show normal recordings of motility 3 months after initial surgery, an oesophageal cannula (internal diameter $27 \mathrm{~mm}$ ) was implanted in the midcervical region. Sham feeding was performed on four occasions in each sheep accustomed to orchard grass hay. The cannula was opened $10 \mathrm{~min}$ before the morning distribution and lucerne hay was given for $30-40 \mathrm{~min}$, during which the ingesta were collected. The cannula was then closed and hay was withdrawn until the evening distribution.

\section{Recordings}

Electrical activity was recorded using a modified EEG machine with a time constant of $0.1 \mathrm{~s}$, and the motility index was obtained by summation of the electrical spiking activity each 20 s (Latour \& Ferré, 1985). Mechanical events were quantified via a Wheatstone bridge amplifier connected to a potentiometric recorder. The area under the curve was taken as an index of contractile activity of the abomasum (Malbert \& Ruckebusch, 1988). Contractions of the reticulo-rumen were designated: $A$, for a response of the reticular strain gauge followed by that of the rumen; $\mathbf{B}$, for a rumen contraction occurring independently of $\mathbf{a}$ reticular contraction. Jaw movements were recorded according to the method already described by Ruckebusch (1963) and plotted on the same potentiometric recorder as the one used for flow measurement.

The gastric outflow was recorded as the passage of digesta through the duodenal ringlike probe (Malbert \& Ruckebusch, 1988). Each passage through the probe of the gastric content was identified, and the net volume propelled forward minus backward flow was measured according to the method previously described and validated (Malbert et al. 1987). The probe was connected to a DC flowmeter recorder (Nycotron, Drammen, Norway) with a low rejection rate and an accuracy of $0.4 \mathrm{ml} / \mathrm{min}$. The flow signal was thereafter computed in line to remove artifacts due to particle attachments. The cumulative flow value (expressed in $\mathrm{ml} / \mathrm{h}$ ) was calculated by the program. The forward and backward digesta movements were termed as direct flow and plotted as $\mathrm{ml} / \mathrm{min}$. The cumulative flow was proportional to the area under the direct flow curve. It was reset to 0 after $100 \mathrm{ml}$ was reached. The whole recording unit was calibrated in vitro using duodenal contents and flow 
was recorded for periods of $72 \mathrm{~h}$ starting $12 \mathrm{~h}$ after insertion of the probe inside the cannula.

Volume and liquid turnover rate measurements

Volumes and liquid turnover rates of both rumen and abomasal liquid phases were estimated by $\mathrm{CrEDTA}$ dilution using a solution containing $100 \mathrm{~g} \mathrm{CrCl}_{3} .6 \mathrm{H}_{2} \mathrm{O}$ and $124 \mathrm{~g}$ disodium EDTA/1 (Gregory et al. 1985). A $20 \mathrm{ml}$ dose of this solution was injected into the abomasum following resumption of duodenal activity at the end of a period of quiescence. Samples of abomasal content $(20 \mathrm{ml})$ were withdrawn via the abomasal tube at $10 \mathrm{~min}$ intervals until $\mathrm{Cr}$ had disappeared. This procedure was repeated four times per animal between 10.00 and 17.00 hours over $2 \mathrm{~d}$ on lucerne- and orchard grass-fed sheep. $\mathrm{Cr}$ concentrations were determined using an atomic spectrophotometer at $357.9 \mathrm{~nm}$ (Binnerts et al. 1968). Estimations of abomasal volume and liquid turnover rate were all carried out according to the method described by Gregory et al. (1985). A $200 \mathrm{ml}$ dose of the same $\mathrm{Cr}$ solution was injected into the rumen at 09.00 hours. Samples of rumen contents $(50 \mathrm{ml})$ were taken at $3 \mathrm{~h}$ intervals over a period of $24 \mathrm{~h}$. The rumen volume was estimated from $\mathrm{Cr}$ concentration extrapolated to time of injection, and turnover rate of the liquid phase was calculated by adjustment of the Cr-dilution curve (Warner \& Stacy, 1968).

\section{Chemical analysis}

DM contents of feed and digesta samples were all determined by drying samples at $80^{\circ}$ over a period of $48 \mathrm{~h}$. Ash content was measured by combustion of samples at $550^{\circ}$ during $6 \mathrm{~h}$ and total $\mathrm{N}$ was determined by the Kjeldahl method. Cell-wall analyses (neutral detergent fibre (NDF) and acid detergent fibre (ADF)) were carried out on dried samples according to the method of Goering \& Van Soest (1970). In vitro DM digestibility was determined by the method of Aufrère (1982) using a cellulolytic enzyme.

\section{Statistical analysis}

Results are expressed as means (with SE) for the intake of orchard grass and lucerne over periods of $5 \mathrm{~d}$ and as means (and SD) for the raw observation of flow and motility index. The significance of treatment differences was examined by analysis of variance.

\section{RESULTS}

\section{Diet composition and daily food intake}

The $\mathrm{N}$ content of lucerne hay was higher and the NDF content lower than those in orchard grass hay (Table 1). However, in vitro DM digestibility was lower for the lucerne hay. The daily DM intake reached 1850-1900 g for lucerne hay compared with 1200-1250 g for the orchard grass hay. The difference in DM voluntary intake between orchard grass and lucerne hay was $76 \%$ within the first day and $59 \%$ during the following $9 \mathrm{~d}$. Conversely, changing from lucerne hay to orchard grass hay reduced DM voluntary intake by $42 \%$ from the first day.

\section{Gastric outflow}

Inserting the electromagnetic probe into the duodenal cannula did not alter gastroduodenal motility. Gastric outflow measured by the flowmeter was enhanced rapidly and reached $51 \%$ of the orchard grass diet value within the first day on the lucerne diet (Fig. 1). No major diurnal variations in the duodenal flow were recorded with the two types of hay.

When the DM intake of lucerne hay was restricted to that of orchard grass hay, gastric outflow was immediately reduced by $24 \%$, but $5 \mathrm{~d}$ were required before an outflow of the same order as that measured with orchard grass hay could be obtained. As expected, the change from lucerne hay to orchard grass hay resulted in a decreased gastric outflow, which was very similar to that previously recorded (see Fig. 1). 
Table 1. Chemical composition $(\mathrm{g} / \mathrm{kg}$ dry matter $(D M))$ of the two hays, orchard grass

(Dactylis glomerata) and lucerne (Medicago sativa)

\begin{tabular}{lcc}
\hline & Orchard grass & Lucerne \\
\hline Organic matter & 926 & 888 \\
Nitrogen & $18 \cdot 3$ & $22 \cdot 8$ \\
Neutral detergent fibre & 699 & 514 \\
Acid detergent fibre & 361 & 370 \\
Acid detergent lignin & $41 \cdot 3$ & $99 \cdot 3$ \\
DM (g/g fresh weight) & 0.901 & 0.850 \\
In vitro DM digestibility $(\mathrm{g} / \mathrm{g})$ & 0.631 & 0.589 \\
\hline
\end{tabular}

\section{Orchard grass}

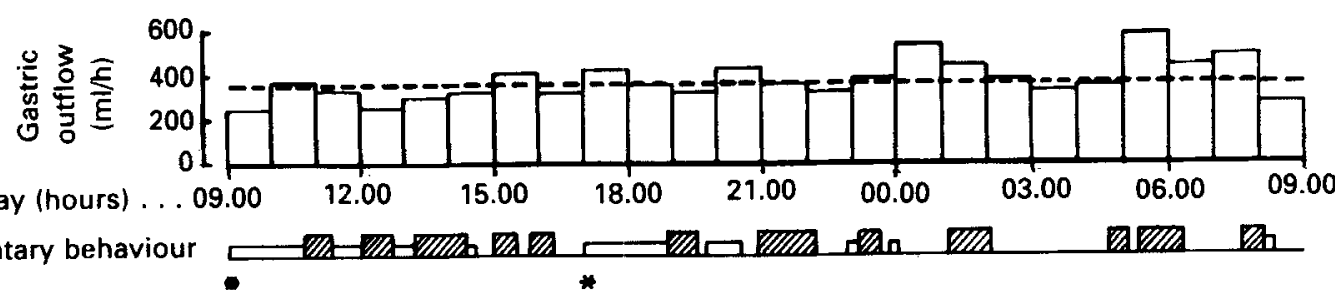

Lucerne

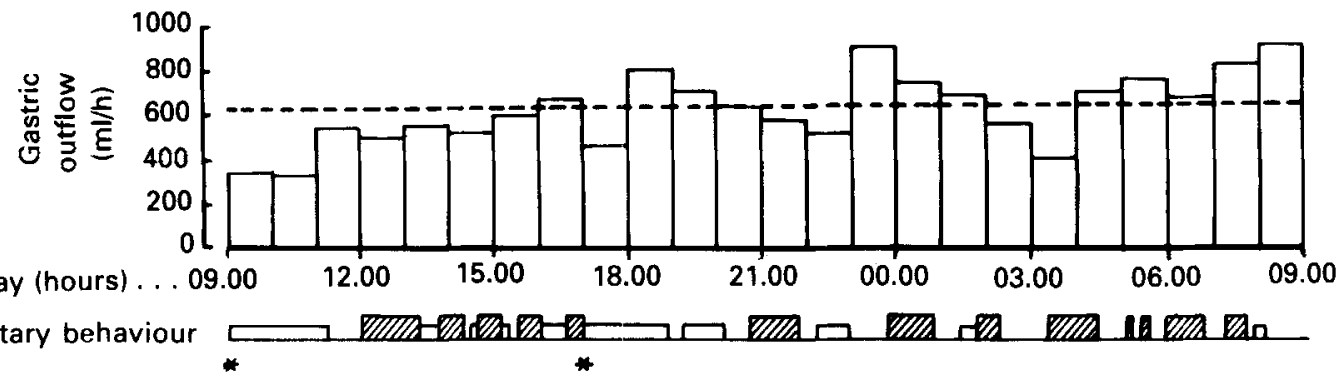

Fig. 1. Gastric outflow (/h) and associated alimentary behaviour, i.e. voluntary intake $(\square)$ and periods

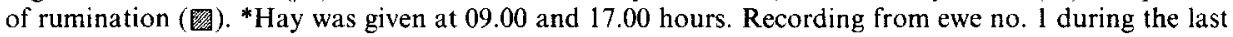
day of orchard grass (Dactylis glomerata) treatment and the first day of lucerne (Medicago sativa) treatment. (--) Mean gastric outflow of orchard grass digesta $(378 \mathrm{ml} / \mathrm{h}$ associated with a dry matter intake of $1070 \mathrm{~g} / \mathrm{d})$ and of lucerne digesta $(625 \mathrm{ml} / \mathrm{h}$ associated with a dry matter intake of $1805 \mathrm{~g} / \mathrm{d})$.

For details of procedures, see p. 701 .

\section{Composition of digesta passing through the duodenum}

Gastric outflow of DM reached $48 \%$ of the amount ingested with the orchard grass hay, $52 \%$ with the lucerne hay fed ad lib. and $50 \%$ with the lucerne hay fed at the restricted level (Table 2). The percentage DM of the duodenal contents was slightly higher when the animals were fed on lucerne hay ad lib. (5.44 (SE 0.13)) than with orchard grass hay (5.24 (SE 0.09)). The flow of $\mathrm{N}$ was twice as high with lucerne hay ad lib. than with orchard grass hay, and remained $25 \%$ higher during the restricted lucerne intake period. Likewise, the amount of cell walls (NDF, ADF) entering the duodenum was increased during the ad lib. lucerne hay period, but remained similar to that measured with orchard grass hay during the restricted lucerne intake period. Therefore, the proportion of NDF ingested entering 
Table 2. Daily intakes and associated gastric outflow during orchard grass (Dactylis glomerata) hay ad lib., lucerne (Medicago sativa) hay ad lib. and restricted lucerne hay periods

(Mean values with their standard errors)

\begin{tabular}{|c|c|c|c|c|c|c|c|}
\hline \multirow[t]{2}{*}{ Treatment* ... } & \multicolumn{2}{|c|}{ Orchard grass } & \multicolumn{2}{|c|}{ Lucerne } & \multicolumn{2}{|c|}{ Restricted lucerne } & \multirow[b]{2}{*}{ LSD } \\
\hline & Mean & $\mathrm{SE}$ & Mean & SE & Mean & $\mathrm{SE}$ & \\
\hline \multicolumn{8}{|l|}{ Food intake $(\mathrm{g} / \mathrm{d})$} \\
\hline Dry matter & 1139 & 83 & 1821 & 96 & 1152 & 79 & 109 \\
\hline Organic matter & 1055 & 75 & 1617 & 85 & 1023 & 71 & 95 \\
\hline Nitrogen & $20 \cdot 8$ & 1.5 & $41 \cdot 5$ & $2 \cdot 2$ & $26 \cdot 3$ & 1.9 & 2.4 \\
\hline Neutral detergent fibre & 796 & 58 & 936 & 48 & 592 & 41 & 64 \\
\hline Acid detergent fibre & 411 & 30 & 674 & 36 & 426 & 29 & 40 \\
\hline Water intake $(\mathrm{ml} / \mathrm{d})$ & 4588 & 379 & 7475 & 464 & 5500 & 244 & 1006 \\
\hline \multicolumn{8}{|l|}{ Gastric outflow (/d) } \\
\hline Total flow (ml)† & 10462 & 1006 & 17238 & 749 & 11875 & 556 & 1352 \\
\hline Dry matter $(g)$ & 551 & 60 & 940 & 61 & 579 & 42 & 98 \\
\hline Organic matter $(\mathrm{g})$ & 488 & 53 & 807 & 56 & 502 & 37 & 68 \\
\hline$N(\mathrm{~g})$ & $17 \cdot 6$ & 1.9 & $35 \cdot 3$ & $2 \cdot 3$ & $22 \cdot 0$ & $1 \cdot 5$ & 3.9 \\
\hline Neutral detergent fibre $(\mathrm{g})$ & 277 & 30 & 343 & 22 & 256 & 39 & 56 \\
\hline Acid detergent fibre $(\mathrm{g})$ & 161 & 16 & 248 & 16 & 174 & 16 & 27 \\
\hline
\end{tabular}

LSD, least significant difference $(P<0.05)$ based on the error mean square with $6 \mathrm{df}$ in the analysis of variance.

* Values evaluated from the results obtained during the last $5 \mathrm{~d}$ of a $10 \mathrm{~d}$ period for the four sheep without antroduodenal strain gauge, fed on orchard grass or lucerne hay ad lib., or when the dry matter intake of lucerne hay was restricted to that of orchard grass hay. (For details of procedures, see p. 701.)

$\uparrow$ Estimated by electromagnetic flowmeter.

the duodenum was little affected by treatments $(35,37$ and $43 \%$ for orchard grass ad lib., lucerne hay $a d l i b$. and restricted lucerne intake treatments respectively). A similar variation was noted in the proportion of ADF (37-41\%).

Measurements of viscosity of abomasal and duodenal contents of sheep fed for more than $3 \mathrm{~d}$ on lucerne and orchard grass hay gave mean values of 45.2 (SE 0.4 ) $\mathrm{cp}$ and 24.6 (SE $0 \cdot 2) \mathrm{cp}$ for orchard grass hay- and lucerne-fed sheep respectively.

\section{Alimentary behaviour}

Although the DM was increased by $60 \%$ (see Table 2) when the animals received lucerne hay ad lib., the time period spent eating was not significantly higher (Table 3). On the other hand, giving lucerne hay resulted in a decrease of $10 \%$ in time period spent ruminating compared with that recorded for orchard grass hay. Therefore, the lucerne hay required less chewing time (eating + ruminating times) per $\mathrm{kg}$ DM and also per $\mathrm{kg}$ NDF intake. Reducing the intake of lucerne hay to the voluntary intake level of orchard grass hay decreased eating and ruminating times, but did not significantly modify chewing time per $\mathrm{kg} \mathrm{DM}$ and per $\mathrm{kg}$ NDF intake.

\section{Volume and turnover rate of ruminal and abomasal liquid phase}

The rumen volume of liquid phase estimated by CrEDTA dilution was not affected by feeding the animals on lucerne ad lib., but the turnover rate of the liquid phase was enhanced by $18 \%$ (Table 4 ). Rumen volume, but not liquid turnover rate, was significantly reduced by the lucerne restricted intake treatment.

No effect of time of dosing was observed on the abomasal CrEDTA dilution curves. The mean abomasal volume was increased by $30 \%$ by giving lucerne hay ad lib., although the 
Table 3. Time-period (min) spent eating and ruminating orchard grass (Dactylis glomerata) hay ad lib., lucerne (Medicago sativa) hay ad lib. and restricted lucerne hay

(Mean values with their standard errors)

\begin{tabular}{|c|c|c|c|c|c|c|c|}
\hline \multirow[t]{2}{*}{ Treatment* ... } & \multicolumn{2}{|c|}{ Orchard grass } & \multicolumn{2}{|c|}{ Lucerne } & \multicolumn{2}{|c|}{ Restricted lucerne } & \multirow[b]{2}{*}{ LSD } \\
\hline & Mean & $\mathrm{SE}$ & Mean & SE & Mean & SE & \\
\hline Eating (E) & 440 & 13 & 449 & 16 & 195 & 9 & 44 \\
\hline Ruminating (R) & 538 & 33 & 480 & 30 & 362 & 5 & 73 \\
\hline $\mathrm{DM}$ intake $(\mathrm{g} / \mathrm{min} \mathrm{E})$ & 2.68 & $0 \cdot 22$ & 4.59 & 0.86 & $5 \cdot 03$ & 0.03 & $1 \cdot 124$ \\
\hline DM intake $(\mathrm{g} / \mathrm{min} \mathrm{R})$ & $2 \cdot 44$ & 0.22 & 4.45 & 0.51 & 0.27 & 0.05 & $1 \cdot 024$ \\
\hline
\end{tabular}

LSD, least significant difference $(P<0.05)$ based on the error mean square with $6 \mathrm{df}$ in the analysis of variance.

* Values evaluated from the results obtained during the last $5 \mathrm{~d}$ of a $10 \mathrm{~d}$ period for the four sheep without antroduodenal strain gauge, fed on orchard grass or lucerne hay ad lib., or when the dry matter intake of lucerne hay was restricted to that of orchard grass hay. (For details of procedures, see p. 701.)

Table 4. Volume and turnover rate of liquid phases of the rumen and the abomasum during orchard grass (Dactylis glomerata) hay ad lib., lucerne (Medicago sativa) hay ad. lib. and restricted lucerne hay periods

(Mean values with their standard errors)

\begin{tabular}{|c|c|c|c|c|c|c|c|}
\hline \multirow[t]{2}{*}{ Treatment* ... } & \multicolumn{2}{|c|}{ Orchard grass } & \multicolumn{2}{|c|}{ Lucerne } & \multicolumn{2}{|c|}{ Restricted lucerne } & \multirow[b]{2}{*}{ LSD } \\
\hline & Mean & $\mathrm{SE}$ & Mean & $\mathrm{SE}$ & Mean & SE & \\
\hline \multicolumn{8}{|l|}{ Rumen } \\
\hline Volume $(\mathrm{ml})$ & 11438 & 657 & 10668 & 256 & 9843 & 433 & 1528 \\
\hline Turnover rate $(/ \mathrm{h})$ & 0.092 & 0.007 & $0 \cdot 109$ & 0.010 & $0 \cdot 102$ & 0.005 & 0.010 \\
\hline \multicolumn{8}{|l|}{ Abomasum } \\
\hline Volume $(\mathrm{ml})$ & 578 & 17 & 754 & 42 & 591 & 19 & 63 \\
\hline Turnover rate $(/ \mathrm{h})$ & 0.94 & 0.07 & $1 \cdot 10$ & 0.02 & $1 \cdot 02$ & 0.04 & $0 \cdot 16$ \\
\hline Outfiow $(\mathrm{ml} / \mathrm{h}) \dagger$ & 542 & 32 & 829 & 45 & 598 & 7 & 133 \\
\hline
\end{tabular}

LSD, least significant difference $(P<0.05)$ based on the error mean square with $6 \mathrm{df}$ in the analysis of variance.

* Values evaluated from the results obtained during the last $5 \mathrm{~d}$ of a $10 \mathrm{~d}$ period for the four sheep without antroduodenal strain gauge, fed on orchard grass or lucerne hay ad lib., or when the dry matter intake of lucerne hay was restricted to that of orchard grass hay. (For details of procedures, see p. 701.)

$\dagger$ Estimated by CrEDTA dilution technique (for details, see p. 702).

nature of hay did not significantly affect the turnover rate. However, its mean value was increased by $17 \%$, so that a larger increase in the net outflow (volume $\times$ turnover rate) can be predicted. The abomasal volumes and outflows measured during the lucerne restricted intake period were not significantly different from those measured with the orchard grass diet.

\section{Reticulo-ruminal motility}

Feeding the animals on lucerne hay increased the rate of A sequence of contractions during eating and rumination, but not during resting (Table 5). This increase appeared from the first day of the lucerne hay feeding period. Restricting lucerne hay intake enhanced the rate of A sequence of contractions during eating. The ratio B:A sequences of contractions was unaffected by treatments, so that treatment effects on the rate of $B$ contractions reflected only those on the rate of $\mathrm{A}$ sequence contractions. 
Table 5. Reticulo-ruminal motility during orchard grass (Dactylis glomerata) hay ad lib., lucerne (Medicago sativa) hay ad lib. and restricted lucerne hay periods

(Mean values with their standard errors)

\begin{tabular}{|c|c|c|c|c|c|c|c|}
\hline \multirow[t]{2}{*}{ Treatment* ${ }^{*}$. } & \multicolumn{2}{|c|}{ Orchard grass } & \multicolumn{2}{|c|}{ Lucerne } & \multicolumn{2}{|c|}{ Restricted lucerne } & \multirow[b]{2}{*}{ LSD } \\
\hline & Mean & SE & Mean & $\mathrm{SE}$ & Mean & SE & \\
\hline \multicolumn{8}{|c|}{ No. of reticulo-ruminal (sequence A) contractions } \\
\hline Eating $(/ \min )$ & 1.25 & 0.04 & $1 \cdot 31$ & 0.03 & 1.43 & $0 \cdot 03$ & $0 \cdot 11$ \\
\hline Ruminating $(/ \mathrm{min})$ & 0.97 & 0.01 & 1.08 & 0.01 & $1 \cdot 16$ & 0.04 & 0.08 \\
\hline Resting $(/ \mathrm{min})$ & 0.76 & 0.03 & 0.79 & 0.03 & 0.75 & $0 \cdot 01$ & $0 \cdot 11$ \\
\hline Total no. (/d) & 1421 & 36 & 1515 & 10 & 1359 & 19 & 81 \\
\hline \multicolumn{8}{|c|}{ No. of ruminal (sequence B) contractions } \\
\hline Eating $(/ \mathrm{min})$ & 0.90 & 0.05 & 1.03 & $0 \cdot 02$ & $1 \cdot 13$ & $0 \cdot 02$ & 0.08 \\
\hline Ruminating (/min) & 0.60 & 0.02 & 0.69 & 0.01 & 0.73 & 0.01 & 0.05 \\
\hline Resting (/min) & 0.42 & $0 \cdot 02$ & $0 \cdot 40$ & 0.02 & 0.39 & 0.01 & 0.07 \\
\hline Total no. $(/ d)$ & 912 & 36 & 996 & 4 & 825 & 12 & 67 \\
\hline
\end{tabular}

LSD, least significant difference $(P<0 \cdot 05)$ based on the error mean square with $6 \mathrm{df}$ in the analysis of variance.

* Values evaluated from the results obtained during the last $5 \mathrm{~d}$ of a $10 \mathrm{~d}$ period for the four sheep without antroduodenal strain gauge, fed on orchard grass or lucerne hay ad lib., or when the dry matter intake of lucerne hay was restricted to that of orchard grass hay. (For details of procedures, see p. 701.)

The daily number of $\mathrm{A}$ sequence of contractions was significantly increased (6.6\%) with lucerne hay ad lib. and that of B contractions by $9.2 \%$. Restricting the intake level of lucerne hay reduced the daily number of A sequence of contractions by $10.3 \%$ and that of $\mathrm{B}$ contractions by $17.2 \%$, due to less time spent eating and ruminating.

\section{Antral and duodenal motility patterns and diet}

The mean antral motor activity of $24 \mathrm{~h}$ was increased by $33 \%$ in lucerne hay-fed sheep (Fig. 2). For both types of diet, the antral activity was represented by three kinds of contraction: weak (less than $3 \mathrm{~g}$ ), strong (less than $5 \mathrm{~g}$ ) and medium (less than $4 \mathrm{~g}$ ), irrespective of their frequency. Considering these three groups of antral contraction strength, the mean frequency of low and middle amplitude contractions was increased with lucerne hay (Table 6). In contrast, the frequency of high amplitude antral contractions associated with propagated duodenal activity remained unchanged (17.9 (SD 8.3) v. 16.7 (SD 12.8)), so that the degree of coordination between antral and duodenal motor activity was not modified.

Changes in the diet did not modify the basal duodenal motility pattern, the phases of RSA of the MMC recurring at the duodenal bulb level at a mean interval of 85 (SD 17.0) min and 90 (SD 14) min for orchard grass and lucerne respectively. The durations of the ISA, RSA and NSA phases did not differ significantly between diets. However, with lucerne hay, a slight decrease in RSA and NSA duration and an increase in ISA (Table 7) were observed. The propagation velocity of the RSA phase recorded from the duodenal bulb site to the transverse duodenum was significantly increased with lucerne (from 0.54 (SD 0.05) to $0.84(\mathrm{SD} 0.13) \mathrm{cm} / \mathrm{s})$. The migration along the proximal duodenum at a higher velocity of the RSA phases was recorded $48 \mathrm{~h}$ after changing the regimen. Higher propagation speed was not obvious for isolated contractions during the ISA phases. The ratio unpropagated: propagated contractions initiated at the duodenal bulb level was similar for the two diets. In addition, the number of propagated duodenal contractions preceded within $5 \mathrm{~s}$ by an antral contraction was unchanged. 
Orchard grass
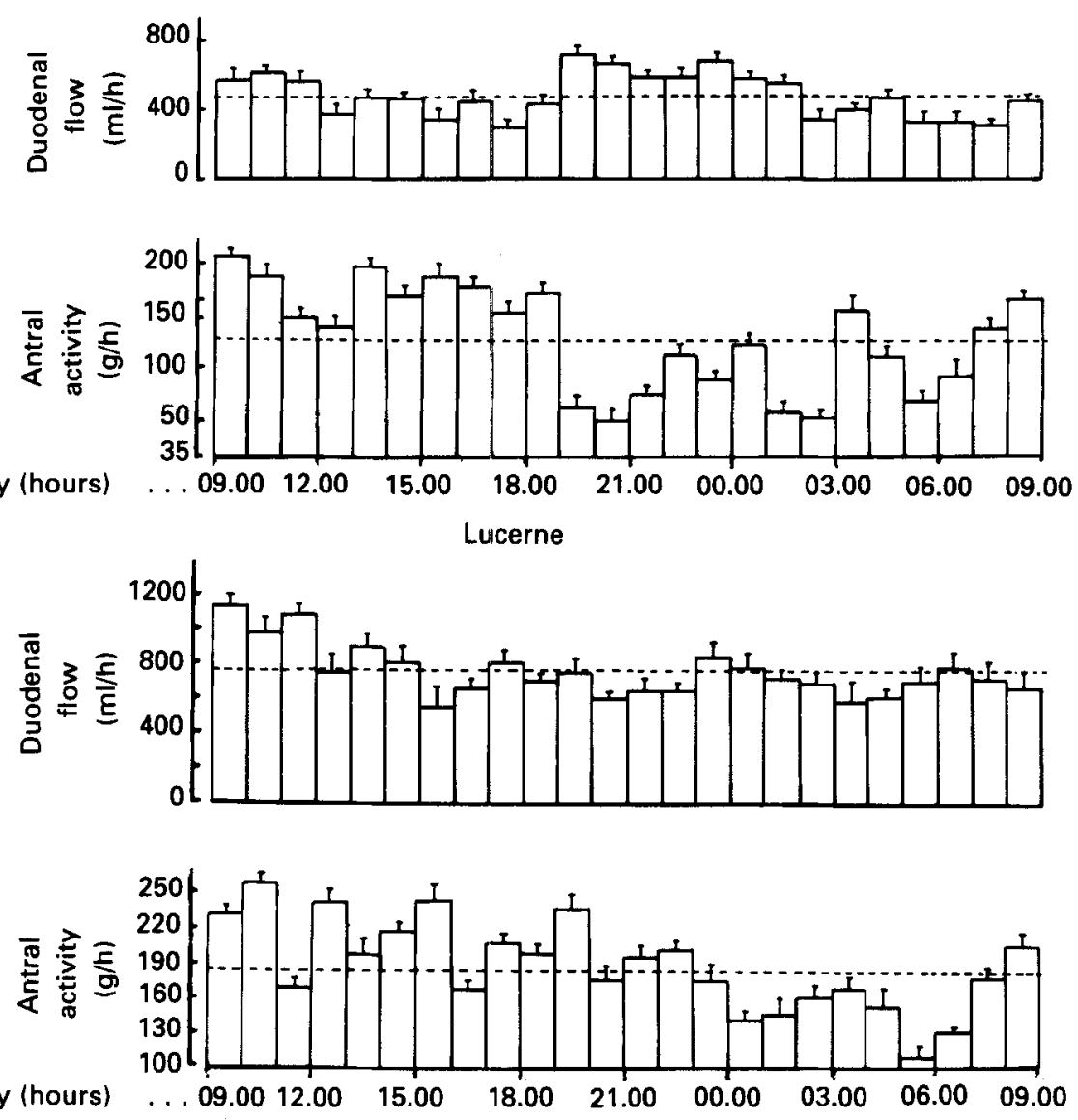

Time of day (hours)

. . $09.0012 .00 \quad 15.00$

Fig. 2. Duodenal flow and motility index of the antrum for $24 \mathrm{~h}$ recordings in three ewes fed on orchard grass (Dactylis glomerata) hay $v$. lucerne (Medicago sativa) hay, given at 09.00 and 17.00 hours. Values are means, and standard deviations represented by vertical bars, at $50 \mathrm{~min}$ intervals for the 4th day (nine observations). (---) Mean values for $24 \mathrm{~h}$.

Table 6. Antral activity measured as the area under the curve of the strain gauge during orchard grass (Dactylis glomerata) v. lucerne (Medicago sativa) hay periods on two occasions in three ewes

(Mean values and standard deviations from eighteen observations)

\begin{tabular}{|c|c|c|c|c|}
\hline \multirow[t]{2}{*}{ Treatment $\dagger \ldots$} & \multicolumn{2}{|c|}{ Orchard grass } & \multicolumn{2}{|c|}{ Lucerne } \\
\hline & Mean & SD & Mean & SD \\
\hline Antral motor activity $(\mathrm{g} / \mathrm{h})$ & $264 \cdot 0$ & $42 \cdot 0$ & $356 \cdot 0^{*}$ & $37 \cdot 0$ \\
\hline No. of antral contractions $(/ \mathrm{h})$ & $109 \cdot 2$ & $5 \cdot 6$ & $195 \cdot 3^{*}$ & $8 \cdot 8$ \\
\hline \multicolumn{5}{|l|}{ Amplitude of contractions $(/ \mathrm{h})$} \\
\hline Less than $3 \mathrm{~g}$ & $57 \cdot 0$ & $5 \cdot 0$ & $105 \cdot 0^{*}$ & $14 \cdot 0$ \\
\hline Less than $4 \mathrm{~g}$ & $35 \cdot 6$ & $4 \cdot 1$ & $72 \cdot 2^{*}$ & $5 \cdot 0$ \\
\hline Less than $5 \mathrm{~g}$ & $16 \cdot 7$ & $12 \cdot 8$ & 17.9 & $8 \cdot 3$ \\
\hline
\end{tabular}

* Mean values were significantly different from those for orchard grass $(P<0.01)$.

+ For details, see p. 701 . 
Table 7. Duodenal activity and flow rate of digesta during three subsequent phases of irregular $(I S A)$, regular $(R S A)$ and no $(N S A)$ spiking activity for three ewes fed on orchard grass (Dactylis glomerata) hay and then on lucerne (Medicago sativa) hay

(Mean values and standard deviations for twenty-seven observations)

\begin{tabular}{|c|c|c|c|c|}
\hline \multirow{2}{*}{ Treatment $\dagger .}$. & \multicolumn{2}{|c|}{ Orchard grass } & \multicolumn{2}{|c|}{ Lucerne } \\
\hline & Mean & SD & Mean & SD \\
\hline \multicolumn{5}{|l|}{ ISA phase } \\
\hline Duration (min) & $85 \cdot 0$ & 17.0 & $90 \cdot 0$ & $14 \cdot 0$ \\
\hline Spike bursts $(/ \mathrm{h})$ & $44 \cdot 5$ & $8 \cdot 4$ & $44 \cdot 1$ & $7 \cdot 4$ \\
\hline Passage of digesta $(/ \mathrm{h})$ & $78 \cdot 3$ & $18 \cdot 3$ & $129 \cdot 3$ & $19 \cdot 3$ \\
\hline Flow $(\mathrm{ml} / \mathrm{h})$ & $482 \cdot 0$ & 0.04 & $753 \cdot 0^{*}$ & 0.06 \\
\hline \multicolumn{5}{|l|}{ RSA phase } \\
\hline Duration (min) & $2 \cdot 82$ & $0 \cdot 16$ & $2 \cdot 81$ & $0 \cdot 31$ \\
\hline Propagation $(\mathrm{cm} / \mathrm{s}) \ddagger$ & 0.54 & 0.05 & $0 \cdot 84^{*}$ & $0 \cdot 13$ \\
\hline Flow $(\mathrm{ml} / \mathrm{min})$ & \multicolumn{2}{|c|}{$<1$} & \multicolumn{2}{|c|}{$<1$} \\
\hline \multicolumn{5}{|l|}{ NSA phase } \\
\hline Duration (min) & $9 \cdot 4$ & 1.9 & $8 \cdot 1$ & 1.5 \\
\hline Flow $(\mathrm{ml} / \mathrm{min})$ & \multicolumn{2}{|c|}{$<1$} & \multicolumn{2}{|c|}{$<1$} \\
\hline
\end{tabular}

* Mean values were significantly different from those for orchard grass $(P<0.01)$.

$\dagger$ For details, see p. 701 .

$\$$ From the duodenal bulb to the transverse duodenum.

\section{Propulsive patterns of digesta and diet (Fig. 3)}

Passage of fluid through the flowmeter probe might occur in association with duodenal contractions or without any sign of electrical or mechanical activity on the duodenal segment. The hourly number of gushes associated with a duodenal contraction was unaffected by the diet. A mean value of $44 \cdot 1-44 \cdot 5 / \mathrm{h}$ was recorded during the ISA phases of the MMC for lucerne or orchard grass hay. However, the total number of gushes was $129 \cdot 3$ (SD 19.3) v. 78.3 (SD 18.3)/h (Table 7) for lucerne v. orchard grass hay-fed sheep. Therefore, the number of gushes of duodenal digesta unrelated to duodenal bulb contractions was 2.5 times more frequent with the lucerne hay diet. The hourly number of duodenal contractions was unchanged for lucerne hay compared with orchard grass hay. In contrast, compared with feeding orchard grass hay, the frequency of antral contractions was significantly increased (see Table 6) with lucerne hay and might be the cause of the greater number of duodenal passages of digesta. The volume of digesta flowing through the probe was fairly constant for the gushes associated with duodenal contractions (5.8 (SE $0.4 \mathrm{ml})$, two measurements which are themselves the mean of 750 gushes on each sheep). Accordingly, the profile of the direct flow trace during lucerne treatment consisted of three to four gushes of varying magnitude intermingled with gushes of uniform volume linked to the duodenal contractions, each of 1.3 (SE 0.04 ) min. Each aboral passage of digesta was immediately followed by retrograde movement of fluid through the probe ring. The amplitude of backflow was minimal and equal to $23 \%$ of the aboral flow in orchard grass-fed sheep. The backflow was equal to $30 \%$ of the aboral flow in the lucerne-fed sheep, hence a higher magnitude of the indentations below the baseline in sheep receiving lucerne $v$. orchard grass.

In sheep fed on lucerne hay, propulsion occurred during the whole ISA phase without major variation in the flow rate. In contrast, with the orchard grass diet, the first and the last parts (with the NSA phase as a reference) of the ISA period were less effective in 
Orchard grass

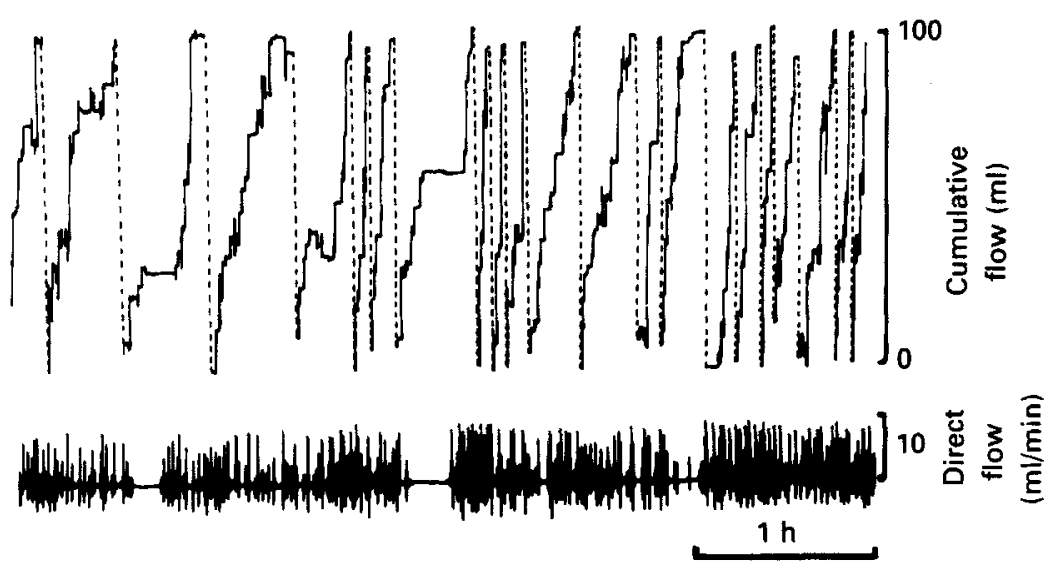

Lucerne
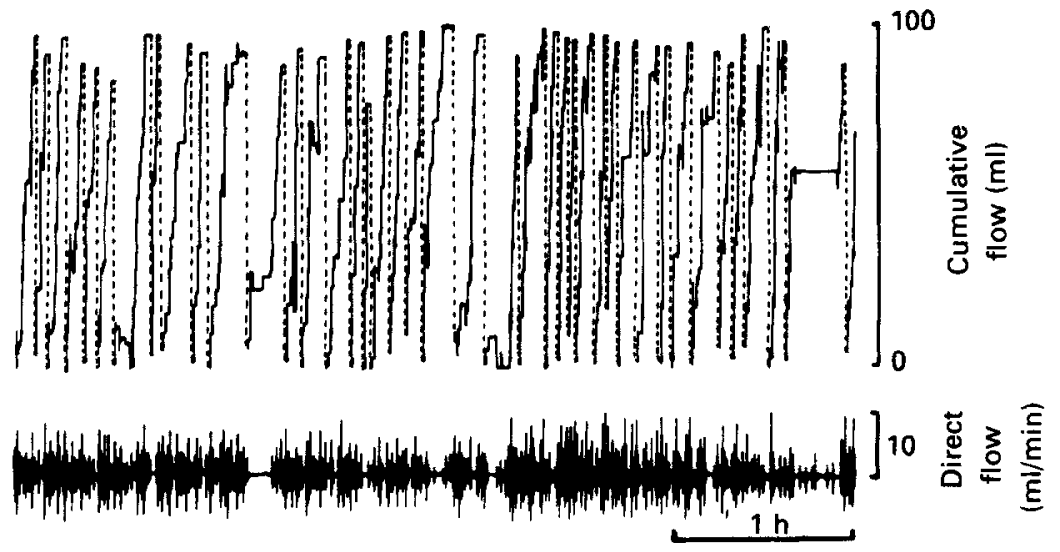

Fig. 3. Influence of the nature of hay on the cumulative and direct flow of digesta measured at approximately $40 \mathrm{~mm}$ from the pylorus. Flow rate was doubled with lucerne (Medicago sativa) compared with orchard grass (Dactylis glomerata) hay. Note the periods of no flow corresponding to the no spiking activity phases, well patterned for orchard grass.

propelling the digesta distally. The amounts of digesta passing through the probe were 33 , 45 and $32 \%$ respectively for the three equal portions of an ISA phase.

\section{Periods of transition and sham feeding}

The duodenal flow was continuously recorded during the periods of transition between the orchard grass hay diet and lucerne hay diet. The flow of digesta increased within 3-8 h after the first lucerne hay meal. This enhanced flow rate was unrelated to duodenal motor activity changes. As soon as lucerne hay was given, small indentations were seen on the direct flow record, without changes in the cumulative flow rate. The origin of these indentations might be unpropagated, i.e. localized contractions sufficient to induce to-andfro movements of digesta into the flowmeter probe ring without changes in the net flow.

A similar increase of the to-and-fro movements of the digesta was recorded after sham feeding procedure with lucerne, i.e. when the oesophageal cannula was opened at the beginning of a lucerne meal. 
(A)
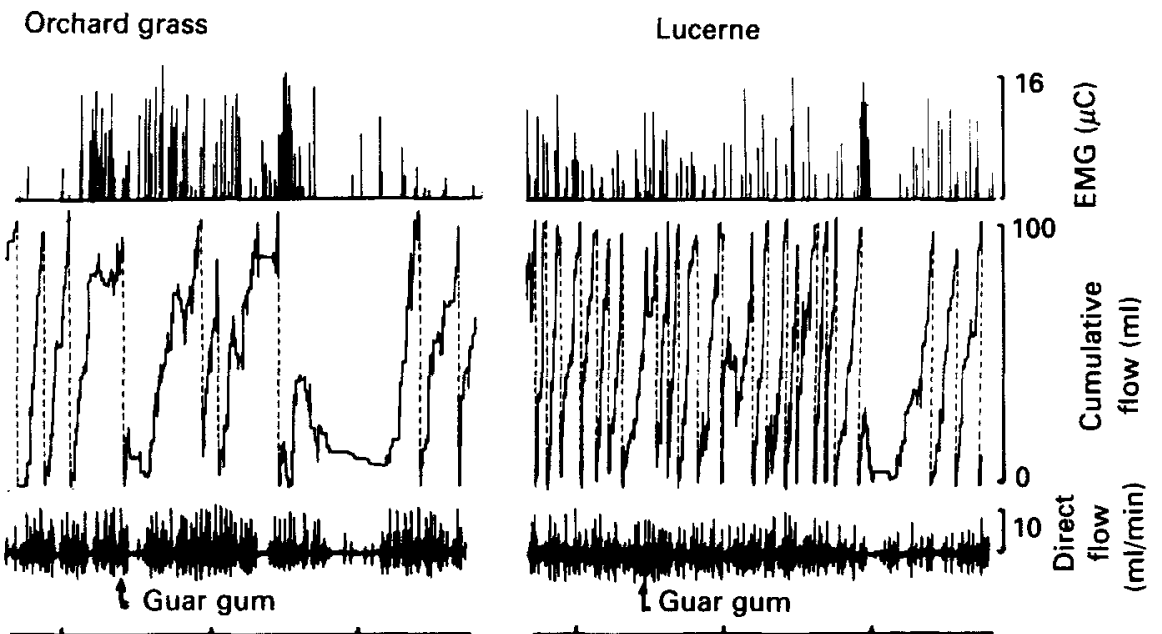

Period of measurement (h)

(B)

Orchard grass
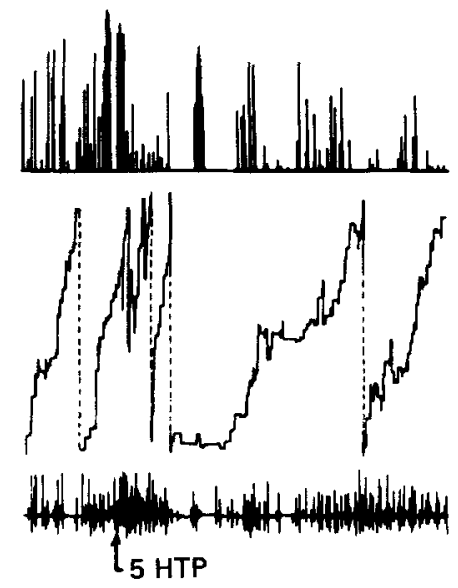

Lucerne
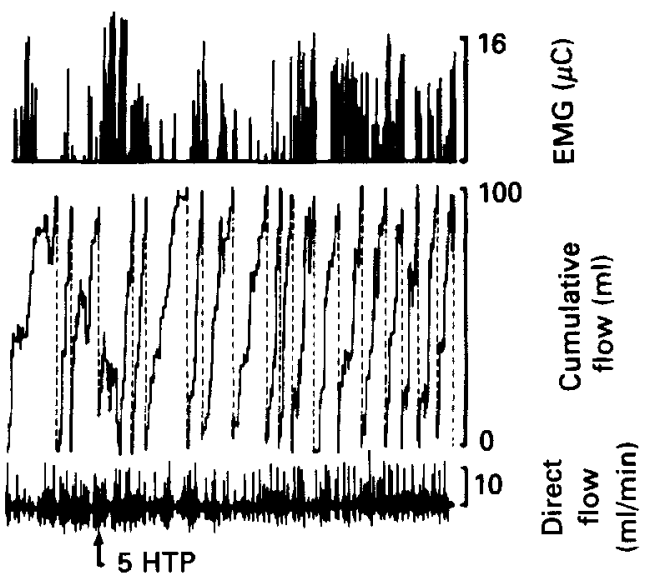

Period of measurement (h)

Fig. 4. Effects of changes in $(A)$ the viscosity of the abomasal contents and $(B)$ the duodenal motor activity on the flow of orchard grass (Dactylis glomerata) $v$. lucerne (Medicago sativa) digesta. Addition of guar gum $(50 \mathrm{~g} / \mathrm{l})$ decreased the flow rate of digesta only in the orchard grass-fed ewe. Impairment of duodenal spiking activity summed due to the intravenous injection $(300 \mu \mathrm{g} / \mathrm{kg})$ of the serotonin precursor, 5-hydroxytryptophan (5-HTP), dramatically decreased the flow rate of digesta in the orchard grass-fed ewe. EMG, electromyographic recording, electrode placed appoximately $50 \mathrm{~mm}$ distal to the pylorus.

Induced changes in viscosity and motility

Increasing the viscosity of the digesta by addition of guar gum into the abomasum reduced by $33 \%$ the flow of orchard grass digesta during a $2 \mathrm{~h}$ period (Fig. $4(A)$ ). The overall profile of duodenal motility was unchanged, but the number of gushes not related to duodenal 
contractions decreased. This lower propulsive activity of the duodenum could be related to a reduced flow rate from the abomasum. A similar increase in the viscosity of the abomasal contents was unable to reduce the flow in lucerne hay-fed ewes, indicating less change in the overall resistance to flow of the lucerne digesta.

The duodenal motor activity was impaired following the administration of 5-HTP $(0.3 \mathrm{mg} / \mathrm{kg})$ and characterized by a continuous spiking activity. The disappearance of the RSA and NSA phases for $3.5 \mathrm{~h}$ resulted in an increase by $30 \%$ of the motility index. In spite of this higher duodenal motility index, the flow rate was reduced by $42 \%$ in the orchard grass-fed sheep (Fig. $4(B)$ ) an effect due to less frequent passage of digesta. In the lucernefed sheep, the flow rate remained high, without reduction in the passage of digesta, despite a similar disruption of the motility pattern.

\section{DISCUSSION}

Previous studies have shown that abomasal and duodenal flows were related to the levels of voluntary intake in sheep (Hogan, 1964; Gregory et al. 1985). But, as far as we know, the onset of variations in flow associated with the change in the diet at different intake levels has never been studied. The continuous recording of minute-to-minute flow rate of chyme through the pylorus over long periods in sheep fed on hay ad lib. (Malbert \& Ruckebusch, 1988) permitted such an evaluation.

A striking feature was the rapidity (a few hours) with which gastric outflow increased when sheep fed on orchard grass ad lib. were changed to lucerne hay. Thus, ingestion of a palatable and rapidly digested forage such as lucerne (Noceck \& Grant, 1987) can increase the outflow of the rumen contents constituted by residues of a more slowly digested forage. In addition, the decrease in gastric outflow also occurred within the first few hours when orchard grass hay was given after lucerne. Such sudden changes in flow associated with the nature of the diet indicated that digestion per se is not a causative factor. It is also noteworthy that the effects of limitation in the level of lucerne intake were gradual.

The gastric outflow measured after the transition period was within the range of values obtained previously by Hogan (1964), $7300 v .20920 \mathrm{ml} / \mathrm{d}$ for $800 v .1700 \mathrm{~g}$ daily intake of lucerne hay; by Grovum \& Williams (1973), $19627 \mathrm{ml} / \mathrm{d}$ for $1200 \mathrm{~g}$ intake of lucerne hay; and by Poncet et al. (1982), $12648-19248 \mathrm{ml} / \mathrm{d}$ for $1200-1500 \mathrm{~g}$ intake. The mean values obtained by CrEDTA dilution are slightly higher than those measured by the flowmeter, since CrEDTA, a water-soluble marker (Downes \& McDonald, 1964), marks specifically the liquid phase of digesta, which flows at a higher rate than total digesta. In addition, the use of CrEDTA may lead to an overestimation in liquid outflow from the abomasum, due to some association of the marker with dry matter (Faichney, 1975).

The apparent disappearance of the DM ingested in the foregut was high. However, values remained within the range (29-65\%) obtained in sheep by Leibholz \& Hartmann (1972) and by Oldham \& Ling (1977) for a variety of diets (concentrates to roughages) using a manual total collection technique for duodenal digesta. The fact that the daily outflow of DM, organic matter and $\mathrm{N}$ remains well related to the amounts ingested is consistent with the results of Ulyatt $\boldsymbol{e t}$ al. (1984) using a double marker technique. The values in Table 2 show that the amount of NDF daily digested in the foregut was only increased by $14 \%$ with the lucerne ad lib., a lower increase than that in apparent DM disappearance $(50 \%)$, in accordance with the cell-wall fraction as a major component of the voluntary intake of forage diets by ruminants.

The increased gastric outflow in sheep receiving lucerne hay ad lib. was associated with a larger abomasal volume, rather than with an increased turnover rate. A similar result was previously obtained by Van Bruchem et al. (1984). Despite a higher level of lucerne intake, 
rumen volume was not increased, in accordance with values obtained by direct measurements (Aitchison et al. 1986) showing a lower rumen fill per $\mathrm{kg}$ DM intake for legumes than for grasses.

From the present findings, the rumen outflow (volume $\times$ turnover rate) was calculated to be 24866 and $27966 \mathrm{ml} / \mathrm{d}$ for orchard grass and lucerne diets respectively. However, steady state conditions did not prevail during such experiments (two food distributions separated by $8 \mathrm{~h}$ ), hence the lack of accuracy for the estimation of rumen outflow by a single dose of CrEDTA (Warner \& Stacy, 1968).

The strong increase in reticulo-ruminal motility at the onset of feeding (Ruckebusch \& Kay, 1971) was more important with lucerne hay than with orchard grass hay, a phenomenon also reported in sheep fed on lucerne hay pellets $v$. fresh ryegrass (Lolium perenne L.) (Waghorn \& Reid, 1983) which can be related to the palatability of the diet. The number of A contractions was increased by $6.6 \% \mathrm{v} .70 .6 \%$ for the DM outflow of orchard grass $v$. lucerne digesta, so that the DM leaving the reticulo-rumen per A contraction was increased by $60 \%$. As suggested by Freer \& Campling (1965) in cattle and by Ulyatt et al. (1984) in sheep, the amount of DM leaving the reticulo-rumen is not controlled by frequency of A sequence contractions.

However, the most striking result was the occurrence of only limited changes in the duodenal motility when the duodenal flow rate was increased by $56 \%$ in the ewes fed on lucerne. The antral motor activity was increased by way of low amplitude contractions (Table 6) unpropagated along the duodenum. Therefore, the frequency of duodenal spike bursts remained unchanged. However, the velocity of propagation of the RSA phase was increased for the lucerne diet without significant variations in the duration of the RSA or the NSA phases (Table 7). Since no increase in the velocity of propagation of the RSA phases was found by Gregory et al. (1985) when the level of food intake of a similar diet was increased, the effect observed with lucerne hay-fed sheep could be associated with changes in physical properties of digesta. On the other hand, an improvement of the coordination between antral and duodenal contractions, as described in dogs for high gastric emptying rates (Kelly, 1980), is unlikely.

The higher flow rate observed for the lucerne diet partly involved an increased volume of the duodenal gushes associated with antroduodenal contractions, and mainly a larger number of digesta movements unrelated to duodenal motor activity. Within a few hours after the first lucerne meal the net flow became largely positive, due to numerous superimposed aboral passages of digesta $(85 v .35 / \mathrm{h})$ associated with small amplitude antral contractions. The occurrence of the supernumerary movements of digesta in lucerne-fed sheep was initially supposed to be linked, directly or indirectly, to the arrival of specific components into the abomasum or the duodenum. Since such movements still occur after diversion of the ingesta by an oesophageal fistula, neural influences have to be taken into account. The peripheral influtences seem to be related to the larger volume of more fluid abomasal digesta.

The importance of the fluidity of the gastric contents in the rate of gastric emptying, mainly that depending on the viscosity, has been demonstrated in the dog (Russell \& Bass, 1985) and the pig (Rainbird \& Low, 1986). Direct measurement of the viscosity of abomasal digesta showed that lucerne digesta is half as viscous as orchard grass digesta (Malbert \& Ruckebusch, 1988). This difference is relatively small compared with the range of viscosity used in the dog to test the effect of viscosity on gastric emptying rate (Ehrlein $\&$ Pröve, 1982). However, unlike the dog where the gastric emptying is discontinuous, the duodenal flow rate is a continuous process in sheep, and thus presents a higher sensitivity to minor changes in fluidity.

The flow was not equally reduced by the same increase in viscosity achieved by addition 
of guar gum in lucerne hay-fed $v$. orchard grass hay-fed sheep. This suggests that the resistance of the antroduodenal area to the flow of orchard grass digesta was much higher than that to lucerne digesta. The dosage used, unable to affect the flow of the more mobile lucerne digesta, reduced to nil the flow of already viscous orchard grass digesta. It is likely that the origin of more important backflow in the vertical part of the duodenum for lucerne $v$. orchard grass diet can be regarded as the result of more fluidity. The reduced viscosity of the duodenal contents in the lucerne hay-fed sheep might be a relevant factor for the propagation at a higher velocity of the RSA phases of the MMC, a phenomenon also recorded on temporarily isolated jejunum in sheep when the contents are removed and replaced by saline.

The authors thank J. P. Serthelon for skilful technical assistance. This work was supported by INRA (Department of Animal Pathology, Paris).

\section{REFERENCES}

Aitchison, E. M., Gill, M., Dhanoa, M. S. \& Osbourn, D. F. (1986). The effect of digestibility and forage species on the removal of digesta from the rumen and the voluntary intake of hay by sheep. British Journal of Nutrition 56, $463-476$.

Aufrère, J. (1982). Etude de la prévision de la digestibilité des fourrages par une méthode enzymatique. Annales de Zootechnie 31, 111-130.

Bell, F. R. \& Grivel, M. L. (1975). The effect of duodenal infusion on the electromyogram of gastric muscle during activation and inhibition of gastric emptying. Journal of Physiology 248, 377-391.

Bell, F. R. \& Watson, D. J. (1976). The influence of gastric distension and the duodenal infusate on the pattern of stomach (abomasal) emptying in the preruminant calf. Journal of Physiology 259, 445-456.

Binnerts, W. T., Van 't Klooster, A. Th. \& Frens, A. M. (1968). Soluble chromium indicator measured by atomic absorption in digestion experiments. Veterinary Record 82, 470.

Demarquilly, C. \& Chenost, M. (1969). Etude de la digestion des fourrages dans le rumen par la méthode des sachets de nylon: liaisons avec la valeur alimentaire. Annales de Zootechnie 19, 419-436.

Downes, A. M. \& McDonald, I. W. (1964). The chromium-51 complex of ethylenediamine tetraacetic acid as a soluble rumen marker. British Journal of Nutrition 18, 153-162.

Ehrlein, H. J. \& Pröve, J. (1982). Effect of viscosity of test meals on gastric emptying in dogs. Quarterly Journal of Experimental Physiology 67, 419-425.

Faichney, G. J. (1975). The use of markers to partition digestion within the gastrointestinal tract of ruminants. In Digestion and Metabolism in the Ruminant, pp. 277-291. [I. W. McDonald \& A. C. I. Warner, editors]. Armidale: University of New England Publishing Unit.

Freer, M. \& Campling, R. C. (1965). Factors affecting the voluntary intake of food by cows. 7. The behaviour and reticular motility of cows given diets of hay, dried grass, concentrates and ground, pelleted hay. British Journal of Nutrition 19, 195-207.

Goering, H. K. \& Van Soest, P. J. (1970). Forage Fiber Analyses. Agricultural Handbook no. 379. Washington, DC: US Department of Agriculture.

Gregory, P. C., Miller, S. J. \& Brewer, A. C. (1985). The relation between food intake and abomasal emptying and small intestinal transit time in sheep. British Journal of Nutrition 53, 373-380.

Grovum, W. L. \& Williams, V. J. (1973). Rate of passage of digesta in sheep. British Journal of Nutrition 29, 13-21.

Hinder, R. A. \& San-Garde, B. A. (1983). Individual and combined roles of the pylorus and the antrum in the canine gastric emptying of a liquid and a digestible solid. Gastroenterology 84, 281-286.

Hogan, J. P. (1964). The digestion of food by the grazing sheep. 1. The rate of flow of digesta. Australian Journal of Agricultural Research 15, 384-396.

Hunt, J. N. \& Stubbs, D. F. (1975). The volume and energy content of meals as determinants of gastric emptying. Journal of Physiology 245, 209-225.

Jarrige, R. (1978). Consommation d'aliments et d'eau. In Alimentation des Ruminants, p. 177 [R. Jarrige, editor]. Versailles, France: INRA Publications.

Kelly, K. A. (1980). Gastric emptying of liquids and solids: roles of proximal and distal stomach. American Journal of Physiology 239, G71-G76.

Latour, A. \& Ferré, J. P. (1985). Computer-aided analysis of gastrointestinal myoelectric activity. Journal of Biomedical Engineering 7, 127-131.

Leibholz, J. \& Hartmann, P. E. (1972). Nitrogen metabolism in sheep. 1. The effect of protein and energy intake on the flow of digesta into the duodenum and on the digestion and absorption of nutrients. Australian Journal of Agricultural Research 23, 1059-1071. 
MacRae, J. C. (1974). The use of intestinal markers to measure digestive function in ruminants. Proceedings of the Nutrition Society 33, 147-154.

Malbert, C. H., Latour, A., Dardillat, C. \& Ruckebusch, Y. (1987). Measurement of gastric emptying rate. Journal of Biomedical Engineering 9, 180-182.

Malbert, C. H. \& Ruckebusch, Y. (1988). Gastroduodenal motor activity associated with gastric emptying rate in sheep. Journal of Physiology 401, 227-239.

Minson, D. J. (1966). The apparent retention of food in the reticulo-rumen at two levels of feeding by means of an hourly feeding technique. British Journal of Nutrition 20,765-773.

Noceck, J. E. \& Grant, A. L. (1987). Characterization of in situ nitrogen and fiber digestion and bacterial nitrogen contamination of hay crop forages preserved at different dry matter percentages. Journal of Animal Science 64, $552-564$.

Oldham, J. D. \& Ling, J. R. (1977). Measurement of the rate of flow of dry matter in digesta passing through the duodenum of sheep. British Journal of Nutrition 37, 333-343.

Poncet, C., Dimova, E., Léveillé, M. \& Dardillat, C. (1977). Mise au point d'une méthode d'enregistrement chronique du débit duodénal chez le mouton. Annales de Biologie Animale, Biochimie et Biophysique 17, $515-522$.

Poncet, C., Ivan, M. \& Léveillé, M. (1982). Electromagnetic measurements of duodenal flow in cannulated sheep Reproduction, Nutrition \& Développement 22, 651-660.

Rainbird, A. L. \& Low, A. G. (1986). Effect of guar gum on gastric emptying in growing pigs. British Journal of Nutrition 55, 87-98.

Ruckebusch, Y. (1963). Recherches sur la régulation centrale du comportement alimentaire chez les ruminants. Thèse Doct Sci Nat, Lyon.

Ruckebusch, Y. (1970). The electrical activity of the digestive tract of the sheep as an indication of the mechanical events in various regions. Journal of Physiology 210, 857-882.

Ruckebusch, Y. (1975). Interaction of duodenal and antral activity in sheep and dogs. Journal of Physiology 254 , $79 P-80 P$.

Ruckebusch, Y. \& Buéno, L. (1977). Origin of migrating myoelectric complex in sheep. American Journal of Physiology 233, E483-E487.

Ruckebusch, Y. \& Kay, R. N. B. (1971). Etude critique de la motricité gastrique chez les ruminants. Annales de Recherches Vétérinaires 2, 99-136.

Ruckebusch, Y. \& Malbert, C. H. (1986). Functional characteristics of the ovine pyloric sphincter. American Journal of Physiology 251, G804-G814.

Russell, J. \& Bass, P. (1985). Canine gastric emptying of fiber meals: influence of meal viscosity and antroduodenal motility. American Journal of Physiology 249, G662-G667.

Singleton, A. G. (1961). The electromagnetic measurement of the flow of digesta through the duodenum of the goat and the sheep. Journal of Physiology 155, 134-147.

Sissons, J. W. (1983). Effect of feed intake on digesta flow and myoelectric activity in the gastrointestinal tract of the preruminant calf. Journal of Dairy Research 50, 387-395.

Sissons, J. W. \& Smith, R. H. (1978). Measurement of flow and sampling of digesta in the preruminant calf. Journal of Physiology 283, 307-317.

Ulyatt, M. J., Waghorn, G. C., John, A., Reid, C. S. W. \& Monro, J. (1984). Effect of intake and feeding frequency on feeding behaviour and quantitative aspects of digestion in sheep fed chaffed lucerne hay. Journal of Agricultural Science, Cambridge 102, 645-657.

Van Bruchem, J., Van Der Lende, T., De Swart, J. G. \& Bangma, G. A. (1984). Abomasal emptying in sheep as related to the amount of protein entering the abomasum. British Journal of Nutrition 52, 123-129.

Waghorn, G. C. \& Reid, C. S. W. (1983). Rumen motility in sheep and cattle given different diets. New Zealand Journal of Agricultural Research 26, 289-295.

Wanderley, R. C., Theurer, B. C., Rahnema, S. \& Noon, T. H. (1985). Automated long-term total collection versus indicator method to estimate duodenal flow in cattle. Journal of Animal Science 61, 1550-1558.

Warner, A. C. I. \& Stacy, B. D. (1968). The fate of water in the rumen. 1. A critical appraisal of the use of soluble markers. British Journal of Nutrition 22, 369-387.

Wenham, G. \& Wyburn, R. S. (1980). A radiological investigation of the effects of cannulation on intestinal motility and digesta in sheep. Journal of Agricultural Science, Cambridge 95, 539-546. 